\title{
A IMPORTÂNCIA DO CHÁ E DO CAVALO NA POLÍTICA DA DINASTIA MING (1368-1644).
}

\author{
NICHOLAS MU-YU CHEN \\ Professor do Curso de Chinês da Faculdade de Filoso- \\ fia, Letras e Ciências Humanas da Universidade de \\ São Paulo.
}

No ano passado, os jornais anunciaram que ilustres sinólogos americanos proferiram conferências sôbre a política do chá e dos cavalos desenvolvida pela dinastia Ming. Os trabalhos dêsses sinólogos não nos chegaram às mãos, mas a notícia nos sugeriu também uma pesquisa sôbre êsse tema, da qual esta nota é um primeiro ensaio, para que êsses acontecimentos, tão interessantes, sejam divulgados no Brasil.

Chá e sêda são dois têrmos usados mundialmente, originários ambos da língua chinesa. Os portuguêses usam a palavra chá; os japonêses ch'a; os árabes chaiy; todos têrmos derivados da pronúncia de vocábulos oriundos das regiões do norte da China. Em alemão temos tee; no inglês tea e no francês thé, oriundos da pronúncia da província de Fugiem (1), onde, ainda hoje, se pronuncia té, como os italianos.

No século VIII, o comerciante árabe Sulimann mencionou' num livro a existência do chá na China. Referia-se êle a uma planta chamada sax. Depois disso não apareceu nenhuma outra referência em livros do Oriente Médio (2). A partir do século XII, com a conquista de Genghis-Khan, o chá começou a ser divulgado.

O autor italiano Ramúsio, em o prefacio do livro (1553 d.C.) A Viagem. de Marco Polo, divulgou na Europa o primeiro texto sôbre o chá. Tivera êle notícia dessa bebida através do comerciante persa Chaggi Memet, em trânsito por Roma. Dissera-lhe o comerciante que os chineses usavam fôlhas de um tipo de planta, o chai-catai. Os chineses valorizavam muito tal planta e ferviam em água suas fôlhas. Usavam a infusão para curar febres, dores de cabeça, dores de

(1). - A província onde se situa a cidade de Zuan-zou que Marco Polo chamou de Zaitun.

(2). - Chang Shing-long, Matérias históricas sôbre a comunicação da China com o Oeste. 
estômago, de rins e também reumatismo. Acreditavam ser o chá remédio para tôdas as moléstias. A tal ponto confiavam em suas propriedades terapêuticas que, em suas viagens, traziam sempre em seus bolsos algumas fôlhas da planta miraculosa (3) .

Os europeus começaram a- tomar chá no século XVII, depois das viagens dos portuguêses, holandeses e inglêses ao Oriente. Os inglêses transportaram as suas plantas e começaram sua cultura na India. Primeiramente trouxeram o chá para Assam e dai o levaram para o Ceilão (4) .

$\mathrm{Na}$ Europa, os russos foram os primeiros a adotá-lo como bebida. Ainda hoje a Rússia consome mais chá do que café como consequiência da facilidade de intercâmbio com a Mongólia e Turquestão. Os russos importavam o chá em forma de tabletes, para facilitar o seu transporte para torná-lo mais econômico, as fôlhas eram prensadas, formando verdadeiros tijolos (5).

No século XV, desde a Ásia Menor até a Rússia, já se consumia considerável quantidade de chá. Contudo, até o segundo quartel do século XIX a China era o único país que o produzia (6).

A troca de chá por cavalos.

A China precisava de cavalos, por ser um país essencialmente agrícola. As áreas cultivadas não deixavam espaço suficiente para a pecuária. Além disso, militarmente havia uma grande necessidade dêsses animais. O malôgro em resistir às invasões pelas tribos nômádes durante o período da dinastia Sung $(960-1279)$ foi a causa da falta de cavalos em número suficiente para fazer uma guerra ofensiva. Isso explica suficientemente o empênho dos governantes da dinastia Ming em conseguir cavalos. A solução foi trocar êsses animais por chá, fato que teve grande repercussão na economia do país.

$\mathrm{Na}$ época do Imperador Hum-u (1368-1398) criou-se uma Secretaria de Estado para cuidar sòmente dos negócios do chá e dos cavalos. Esse órgão governamental recebeu o nome de Cha-ma-si e monopolizou o comércio proibindo a exportação do chá por particulares. O genro do Imperador, observando os lucros das transações, tornou-se contrabandista de chá. Chegando o fato ao conhecimento do Imperador, reprimiu êste violentamente o abuso. Puniu com a morte o seu desleal parente. Isso bem mostra a importância que se dava a êsse comércio para a vida do país (7).

(3). - Ibidem.

(4). - Raymond Dawson, The legacy of China, pág. 353. pág. 220.

(5). - L. Carrington Goodrich, $A$ short history of the chinese people,

(6). - Raymond Dawson, op. cit., pág. 353.

(7). - Chia-sheh, Ming Tung Gian, volume II, pág. 675 . 
A troca de chá por cavalos não foi, a princípio, muito vantajosa. Os cavalos saiam por um preço muito elevado; 80.000 zins (medida de pêso chinês, 1 zin eqüivalia mais ou menos a $2 / 3$ de quilo) por apenas 70 animais. Com o tempo, porém, a situação foi melhorando. Em 1408, já está escrito no livro oficial da História da China que por 500.000 zins de chá se obtinham 3.800 cavalos. Isso significa que o consumo do chá difundia-se e se intensificava nos países limítrofes do Oeste (8).

Também foi fator desfavorável para o início do intercâmbio a distância em que ficavam os postos de troca no interior:

"No comêço do estabelecimento de Cha-ma-si, na época do Imperador Hum-u, os estrangeiros levavam os cavalos para Ya-zou (na província Si-kong). Cada cavalo custava então 1.800 zins de chá. Porque viajavam por longas distâncias, os estrangeiros queriam ser altamente recompensados. $O$ govêrno de Ien-zou pedia que $\circ$ mercado mudasse para essa localidade. O Imperador decretou preços para os cavalos; um cavalo superior custaria cento e vinte zins, um médio setenta e um potro, cincoenta" (9).

Posteriormente, mudou-se o mercado para a província de Shensi, mais para o Ocidente. O Imperador ordenou ao Ministro da Fazenda, Yusin, que, com o chá de Hanzuen, Shensi poderia trocar três milhões de zins por 30.000 cavalos (10).

Criação de cavalos.

Em 1375 o Imperador baixou um decreto pelo qual enfatizava a importância política de obtenção de cavalos para o país, e em consequêencia criou uma Secretaria de Estado, chamada Tai-pu-chei para o incremento da criação de eqüinos. Em 1413, nôvo decreto ordenava que, ao sul do rio Yang-tzi, onze famílias deveriam criar cada uma um cavalo. Ao norte do rio, cinco famílias também deveriam fazer o mesmo. Havia mesmo inspetores para garantir o cumprimento da ordem. Se um inspetor notasse que um cavalo estava magro ou maltratado, o criador descuidado seria punido (11).

Para os militares também havia uma regulamentação para o uso dos animais. Os soldados não deviam servir-se dêles para passeios ou para tarefas de interêsse pessoal. A desobediência às prescrições regulamentares acarretava severos castigos. Daí compreendermos o tratamento e os privilégios de que gozavam êsses animais (12).

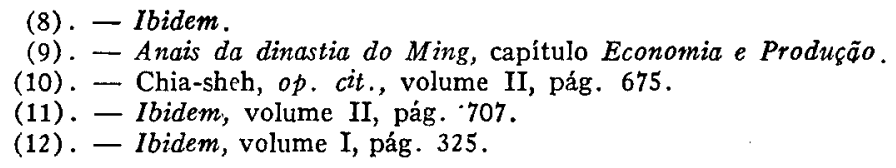


O Imperador estipulou também que o pagamento dos tributos devidos pelos países protegidos poderia ser feito em animais. Cita-se o caso da Coréia, que de uma feita pagou ao govêrno chinês o seu tributo com 3.000 cavalos (13).

Os Anais da dinastia Ming, mencionam que por volta de 1421 o Imperador recebeu uma carta de So-tsi, professor da Academia Real nos seguintes têrmos:

"O Govêrno, cada ano, manda o povo fabricar brocados de sêda e envia também eunucos para o Oeste a fim de comprar cavalos. Os eunucos gastam milhões e trazem animais de espécie inferior, velhos ou doentes. A diferença de preço é embolsada pelos enviados. Deixam os animais aos cuidados do povo. Naturalmente os cavalos morrem com facilidade e o govêrno onera o povo com multas eqüivalentes ao preço de animais de espécie superior. Há casos em que o agricultor de poucos recursos, incapaz de pagar o devido preço, tem de vender sua espôsa ou filhos para saldar sua dívida. Isso é uma maldade, uma política errônea que desprestigia o govêrno. Necessárias se fazem, portanto, medidas que corrijam êsse êrro" (14).

Em 1424, um alto funcionário do Ministério de Cerimônias, chamado Van-zi, três vêzes enviado como embaixador ao Oriente Médio, também escreveu ao Imperador denunciando as fraudes dos emissários que tinham ido à Ásia Menor. Afirmava serem êles, na realidade, falsos mensageiros, comerciantes charlatães, em sua grande maioria:

"Vêm à China disfarçados em enviados de reis para prestar tributos ao Imperador. Na realidade, porém, são aventureiros e falsários enviados por comerciantes ávidos de lucros fáceis. São bem tratados nos postos do govêrno (espécie de hospedarias), onde recebem alimentação, boa e farta, e até mesmo condução. Recebem ainda do Imperador ricos presentes para seus supostos soberanos, além de alta remuneração. Por causa dêles, os estrangeiros todos querem aproveitar essa fonte de riqueza e mensalmente chega à China uma grande leva de emissários que, satisfazendo a vaidade do Imperador, carrega daqui abundantes riquezas. Voltando aos seus países transportam, por vêzes, mais de cem carros com mercadorias de grande valor. Muitas dessas mercadorias são ganhas e outras obtidas por baixo preço. No caminho de volta, obrigam os camponeses a ajudá-los no transporte, utilizando-se, para isso, até de mulheres e crianças. Maltratam os oficiais das hospedarias, chegando a espancá-los com

(13). - Ibidem, volume I, pág. 438.

(14). - Ibidem, volume II, pág. 746. 
chicotes. E ninguém se encoraja em reagir, pois são considerados como enviados do Imperador" (15).

Sugeria então Van-zi que o Imperador só aceitasse cavalos como presentes. Exclusivamente cavalos, nada de pedras e cousas inúteis. Ainda mais, os cavalos não deveriam ser levados à capital, mas deixados perto da fronteira. num lugar chamado Can-su. Assim, por-se-ia têrmo ao abuso.

Em 1425 o Ministro da Defesa sugeriu ao Imperador medidas que incrementassem a criação de cavalos. Assim, dizia êle:

"Este ano a criação de cavalos teve bons resultados. Além de suprir as necessidades do exército, ainda houve uma sobra de alguns milhares. A melhor maneira de aproveitar o excedente é deixar os animais em mãos dos funcionários públicos. Cada funcionário deverá cuidar de um animal e, no fim do ano, entregar ao govêrno um potro" (16).

O Primeiro Ministro, entretanto, manifestou-se contràriamente a tal sugestão, alegando que isso seria rebaixar os funcionários à condição de criadores de cavalos.

\section{Plantação de chá.}

Pelas estatísticas do Ministério da Fazenda pode-se ver que sòmente nos distrito de Hajen, Hanguen, Gingiou, Pinli e Chincheon (mais para o Ocidente), havia 4.415 mus (unidades agrárias) plantados em chá com 860.000 árvores. Os Anais do Império de Wan-li indicam que havia anualmente uma troca de 11.900 cavalos por chá. Calculou-se a exportação de chá em aproximadamente 1.100 .000 zins (17).

A partir da dinastia Ch'ing (1645-1911) o Oeste da China deixou de produzir chá. O centro da produção transferiu-se para An-ue, Geonshu, Geh-geon e Fugiem, localidades mais próximas do litoral. Isto significa que já haviam chegado à China portuguêses, holandeses, inglêses e franceses pelo mar e exportavam-no para a Europa. Os persas, árabes e turcos perdiam assim o imenso prestígio que até então tinham gozado no comércio do chá.

Os chineses não cultivavam o chá como indústria. Plantavam-no no sopé das colinas, em região de clima quente e terreno mais ou menos árido, que não se prestasse ao cultivo do arroz e de outros gêneros considerados como de primeira necessidade. Isso trouxe como conse-

(15). - Ibidem, volume II, pág. 778.

(16). - Ibidem, volume II, pág. 780.

(17). - Chie-yu-zeong, Geografia histórica da China. 
quiência uma grande variedade de produção; encontram-se ainda hoje na China centenas de espécies de chá. Enquanto isso, os inglêses racionalizavam a cultura do chá e padronizaram a produção. Daí o maior desenvolvimento de produção na India e em algumas colônias britânicas.

\section{Conclusão .}

Vimos, agora, que os animais domiciliados foram importantes na história humana; como o cavalo na técnica da guerra e o gado no desenvolvimento da agricultura. ( $\mathrm{Na}$ China tem gente que não gosta de carne de vaca, assim como também os hindus tratam o gado como um animal sagrado). Na literatura chinesa encontramos vários versos que descrevem a beleza e o característico heróico do cavalo. Nas pinturas chinesas existem muitas obras afamadas sôbre retratos de cavalos; algumas delas foram intituladas como "O Quadro do Kavalo Celestial". O cavalo de Alexandre-o-Grande, na história helênica, chamava-se "Bucéfalo", na China também existia um cavalo bem conhecido pelo povo chinês chamado "Ch'eh-tu" (coelho vermelho) que foi o cavalo do general Kwan-gueão, um grande guerreino e um herói na época de "Três-reinos" (220-280 d.C.).

Na história da China, o chá, a sêda e a porcelana foram as produções mais rendosas para o país, que enriqueceram a nação e abençoaram o padrão de vida do povo chinês em geral. Depois, quando outros países começaram a produzir os mesmos artigos com método mais adiantado, a China ainda insistia no uso da mesma técnica de produção, perdendo provàvelmente o prestígio no mercado internacional. Isto é um acontecimento que merece de ser estudado, mesmo para o Brasil relativamente ao café. 